Cahiers « Mondes anciens »

ANCIENS

Histoire et anthropologie des mondes anciens

5 | 2014

Maudire et mal dire : paroles menaçantes en Grèce ancienne

\title{
Oedipus Abuser: Insult and Embodied Aesthetics in Sophocles
}

\section{Nancy Worman}

\section{(2) OpenEdition}

Journals

Electronic version

URL: http://journals.openedition.org/mondesanciens/1237

DOI: $10.4000 /$ mondesanciens. 1237

ISSN: 2107-0199

Publisher

UMR 8210 Anthropologie et Histoire des Mondes Antiques

Electronic reference

Nancy Worman, "Oedipus Abuser: Insult and Embodied Aesthetics in Sophocles », Cahiers " Mondes anciens » [Online], 5 | 2014, Online since 14 February 2014, connection on 01 May 2019. URL : http:// journals.openedition.org/mondesanciens/1237 ; DOI : 10.4000/mondesanciens.1237

This text was automatically generated on 1 May 2019.

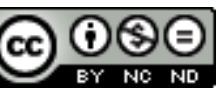

Les Cahiers «Mondes Anciens » sont mis à disposition selon les termes de la licence Creative Commons Attribution - Pas d'Utilisation Commerciale - Pas de Modification 4.0 International. 


\title{
Oedipus Abuser: Insult and Embodied Aesthetics in Sophocles
}

\author{
Nancy Worman
}

1 There is an arresting moment in the Poetics, one that often confuses or repulses readers, when Aristotle claims that viewers of tragic spectacle take pleasure in the imitation ( mimesis) even of hideous things: "What we view with pain," he says, "images of these same things, especially when very precisely rendered, we enjoy gazing upon, as with

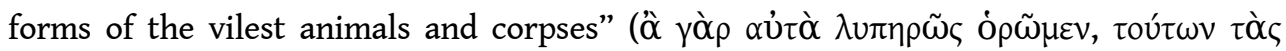

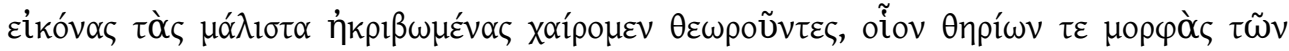

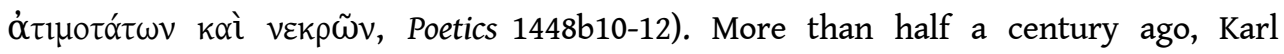
Reinhardt, in a famous essay on Oedipus that influenced Heidegger, argues that "peculiar to Attic tragedy as a whole" is "the habit of luxuriating in horror, of investing terror with a kind of voluptuousness." Julia Kristeva has explored the affects generated by something that seems at first like the opposite of this effect: the abject - the untouchable, barely conscionable, and yet compelling outcast object - and one of her favorite examples is the dilapidated Oedipus ${ }^{2}$. Kristeva regards Oedipus at the end of the Tyrannos play as most importantly what Creon terms him: an agos (Oedipus Tyrannos 1426), a figure of pollution that indicates the deep well of unknowing in all of us.

2 So here are three quite distinct reactions to bodies subject to tragic defilement, from three rather different intellectual perspectives: 1) tragic mimesis of horrifying figures is enjoyable and informative (Aristotle); 2) tragic characters and audiences take fascinated pleasure in viewing horrors (Reinhardt); and 3) tragically debased figures arouse in viewers a sense of horror that is also captivating (Kristeva). While even modern scholars as theoretically and politically distinct as Reinhardt and Kristeva share a sense that an unnerving combination of shame and attraction may attach to the experience of viewing such sights and perceiving their impact in language, Aristotle instead emphasizes the act of reproducing (mimêsis). This he considers itself a thing of great value, if well executed. From his perspective the spectacle of debased bodies would give a more straightforward, enlightening pleasure, but for him this is secondary, since he does not consider visual 
effects to be very central to the dramatic idiom. So if we want to pursue the hybrid impact of tragic representation more fully, what about how such bodies are depicted at drama's unique intersection - that is, at points where targeting, directive language suggests or indicates spectacular details, where imagery and illustration together create the effect?

3 I shall focus in the paper on one such intersection, namely insult and bodily stature, as these converge in particular relation to Aristotle's favorite tragic plot: that of Sophocles' Oedipus. I am interested in trying to understand how Sophocles encourages us to regard this hero, both aesthetically and ethically, by means of the peculiarities of abusive practices within the dramatic medium. That is, how do Sophocles' characters - including the heroes themselves - envision the heroic body and target it through insult? When do they tell the audience what to see, how to look, especially in the tensions generated between tragedy's elevation of heroes and their devolution into objects of abuse? As I have argued elsewhere, when addressing insult one needs to take account of both the abuser and the abused, and the most interesting figures tend to be both ${ }^{3}$. One of the especially notable things about Oedipus, but something that scholars have not shown much curiosity about, is the ways in which his status and stature do not match his modes of speech. He is at his most blunt and insulting when most elevated and grand; and, conversely, often gracious and delicate in his verbal negotiations when most debilitated ${ }^{4}$.

4 I submit that tragedy contributes something unique to these intersections of the body and language, that this contribution has to do with what we might term the aesthetics of abuse, and that these are dependent on the layered quality of dramatic semiosis, which builds up from the language of the text to the possibilities of its performance ${ }^{5}$. Within this dramatic frame, the most debased and targeted of forms may replace the most heroic as objects of reverence precisely because of the paradoxical qualities of tragedy's aesthetics. And, conversely, the glorified figure may appear debased, by virtue of his mistaken place in the order of things. So, to take my main example, the lofty Oedipus issues curses at an as yet unidentified criminal, a kakourgos of the basest sort, and threats to a blind and decrepit seer. His insults revolve ultimately upon his own status and stature, since he emerges as the target of his abuse, both criminal and blind; and only then might he, in this new debilitated state, become an object of tragic pleasure. For Reinhardt Sophocles' Oedipus alone "luxuriates, writhing and pointing to himself, flowering in his torment"; and although other Sophoclean heroes surely do exactly this (witness Ajax in his swag of corpses, Heracles on the bier), Reinhardt's language captures some of the curious effects I aim to address ${ }^{6}$.

\section{Oedipus Insulting and Accursed}

In Oedipus the King the eponymous hero is so isolated in his high prospect that he scorns the perspectives of others and closes off in any possibility of debate. He is by turns patronizing and abusive, the ruler whom his subjects address as close to the gods, most powerful, and magnificent. His cleverness combined with his high-handed attitudes toward those around him insures that it is his plot alone that unfolds, so that he is uniquely responsible for his precipitous fall in stature ${ }^{7}$. At the outset of the play the priest

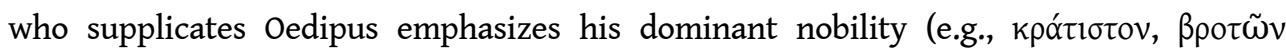

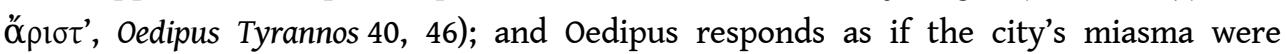
uniquely his to dispel - which of course it is, though not as the wise solver of riddles he 
takes himself to be. As scholars have noticed, a priest and a crowd of young men are

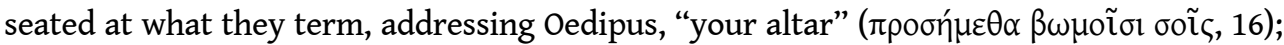
though it is in fact dedicated to Lycean Apollo (as Jocasta notes later on, 919). They

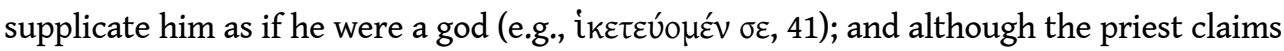

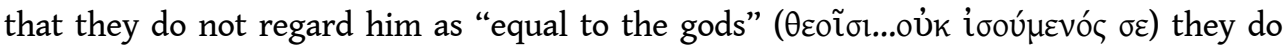
deem him "first of men in the circumstances of life when in converse with the gods"

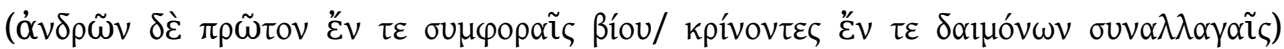
$(31-34)^{8}$. After hearing Creon's news from Delphi identifying Laius' murderer as the cause of the city's miasma, he curses this outlaw, publicly and powerfully. The curse is unstinting and brutal in the extreme: that the guilty man be rejected utterly, banished from the land unwelcome and unheard, shoved from all houses and prohibited from all

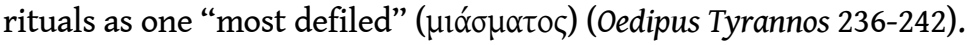

The path to Oedipus' perspectival and physical reversal is a tortuous one. It takes the turn most important for my focus on the intersection of ethics and aesthetics in an agonistic exchange early on in the drama, in which Teiresias warns Oedipus of his terrible devolution, the vision of which is so cruelly dismantling of his kingly status that he cannot countenance it. He responds with violent anger, brutal insults, and a telling myopia, as if the seer's words were calculated only to provoke and deceive him ${ }^{9}$. Oedipus greets Teiresias graciously enough, even figuratively relinquishing his status as the one to whom appeals are made, "Since, as he says, we all here are prostrate before you as

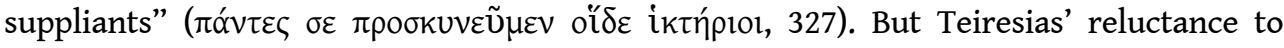
speak the brutal truth provokes Oedipus, so that he is soon addressing him as "worst of

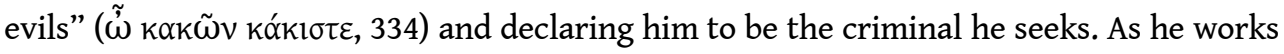
himself up, both he and Teiresias remark on temper and temperament (orgê), which the seer declares is hindering Oedipus' understanding. Fittingly, Oedipus hears the term as designating anger rather than disposition. When Teiresias says, "You blame my

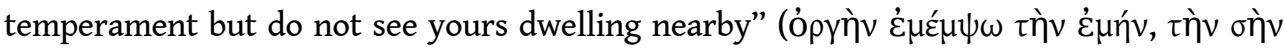

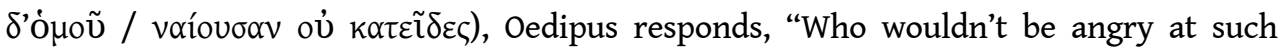

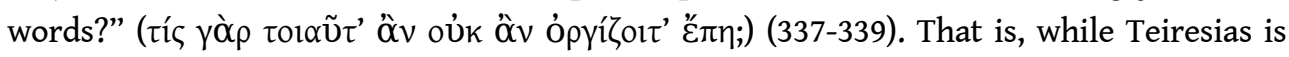
highlighting their different attitudes and saying what he knows to be true, Oedipus takes his careful commentary and reluctance to speak as insult, so that the scene unfolds in a kind of hybrid mode, with the blind old prophet reluctantly talking truth to power and the king hearing this truth as abuse ${ }^{10}$.

7 And it is this division of modes (i.e., truth-telling or prophesy versus invective) that makes it possible for Teiresias to reveal the end of the story, the answer to the mystery, without effectively ending the play. When Teiresias states flatly to Oedipus, "You are the city's miasma," he does so in response to a similar charge from Oedipus (346-349), so that the king receives the claim as a taunt thrown out shamelessly ( $\dot{\alpha} v \alpha 1 \delta \tilde{\omega} \varsigma, 354)$. An even more direct statement elicits the same reaction. To Teiresias' flat declaration, "I say that you are the murderer for whom you seek punishment” (

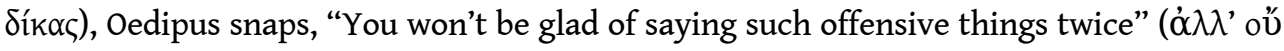

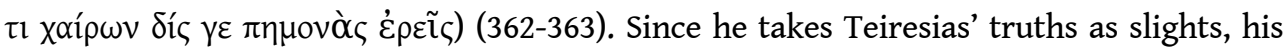
anger dominates the scene (cf. 343-346), skewing his perspective and that of the internal audience (i.e., the chorus). Further, the split in modes aligns the external audience, who know the famous plot if not all of its details, with the frail seer and reveals the domineering king as blinded by his own anger. This formal face-off between abusive attacks and prophetic revelations highlights insulting modes themselves as potentially 
deluding, since in the throes of anger one may hear statements of fact as taunts given in response to one's own. Thus Oedipus hears the truth in a temper and effectively listens not at all. Instead he accuses Teiresias of being "blind" in all of his senses: "in ears and

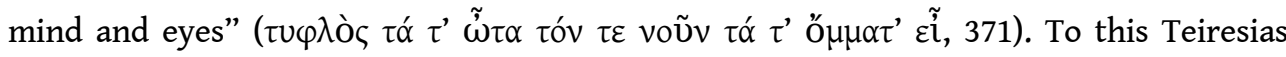
replies, in a moment full of foreboding, "And you are in fact wretched uttering these

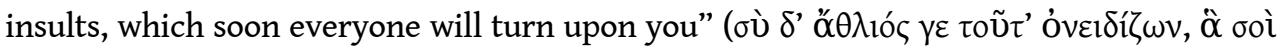

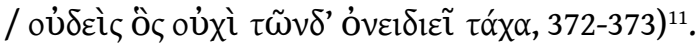

8 This threat of his abuses' imminent revolution drives Oedipus to expound at greater length upon his sense of betrayal. He invokes his own wealth, sovereignty, and "skill

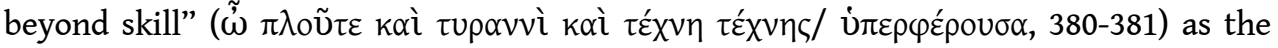
source of Teiresias' slander (as he considers it), claiming that Teiresias and Creon are plotting against him. His language reinforces the impression of his high-handed and insulting attitude; Creon, he says, desires to overthrow him and thus has sent in "this

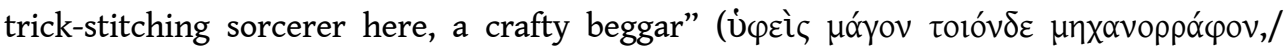

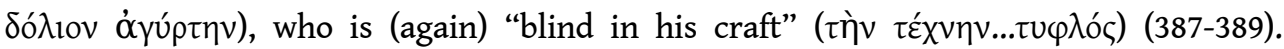
Oedipus also points out that unlike Teiresias he solved the Sphinx's riddle, so that in his accounting the sovereign has all the skill that the seer ought to possess.

9 Teiresias responds to Oedipus' invective by once again rebounding the king's taunts about his debilities and emphasizing the abusiveness of his tone. In a matched reversal of terms that succinctly clinches status and stature, the blind seer asserts his independence and his insight:

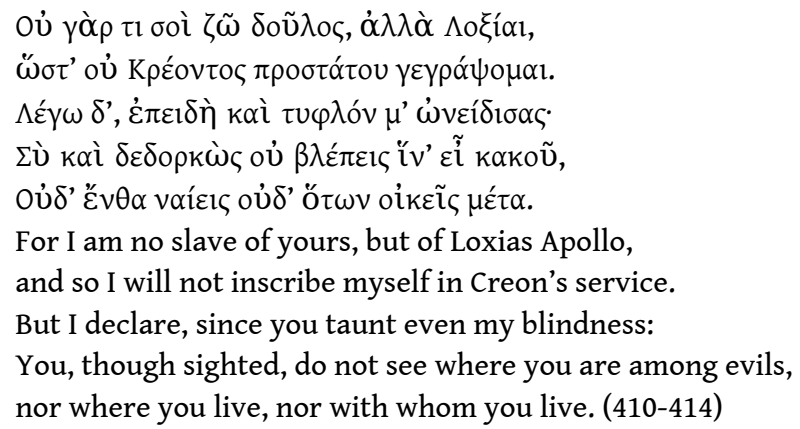

10 The seer goes on to deform the king's glorious stature into a monstrous entity: a "double-

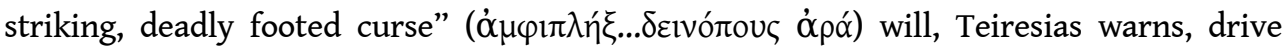
Oedipus from the land, in shadow (бKótov, i.e., blind), and with no harbor or mountain crag empty of his cries (417-421). He concludes with a familiar metaphor for abusive gestures: "Go ahead," he says, "sling mud at both Creon and my mouth; but no one will be

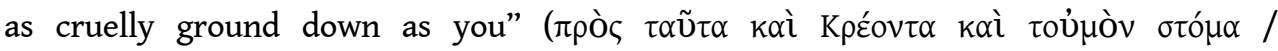

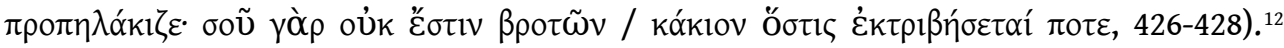
After Oedipus has furiously ordered Teiresias to leave, the seer offers the king one more parting image. Perhaps driven to a somewhat cryptic mode by Oedipus' violent responses,

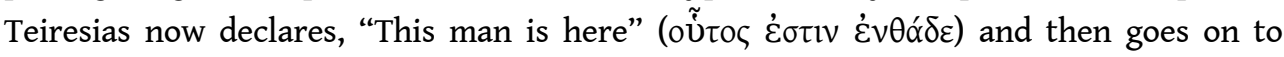
envision "this man" as a blind beggar, tapping out his way in a strange land with a stick

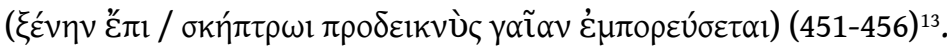

11 Teiresias' responses reduce the body of the king in visceral terms, so that here for the first time the tragic language throws up a shadow figure, the shape of things to come: the cursed, blind, and friendless outcast. The menacing language of these exchanges thus shapes a stark contrast between the king's commanding presence visible on stage and his future self. This unnerving mismatch offers the audience the shudder of horrified 
recognition and the chance to be more knowing than the most knowing of aristocratic leaders. It also encompasses the plot in one elegant gesture that is aligned with simple truth-telling and prophesy, while coupling insult with ignorance born of overweening anger and a self-regarding myopia. Further, truth is embodied as frail and blind, while insult resides in the robust and superior figure.

Oedipus' confidence, verbal harshness, and physical dominance wane incrementally, but as with Heracles in the Trachiniae the drama does not really center on his actual physical form until late in the action, when it is no longer splendid. Indeed, it is only here, at the end of the play, that Oedipus assumes a physical stature so counter to his intellectual and political one as to be singularly horrifying - and therefore, as Reinhardt would have it, tragically stunning in the "flowering" of its awful regard. He devolves into the "wretched form" (ö $\theta \lambda_{1 o v} \delta \varepsilon ́ \mu \alpha c$, Oedipus Tyrannos 1388; cf. Oedipus at Colonus 576, Trachiniae 1079) offered to view near the drama's end, a polluted thing that shocks Creon by its

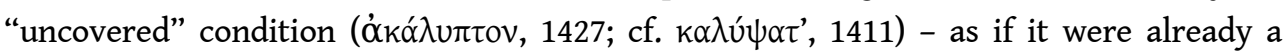
corpse (cf. Ajax 916, 1003, Antigone 28, Trachiniae 1078).

13 And yet Oedipus does indeed seem to "luxuriate" in his new state, a perversely aestheticizing and manipulative extension of the play that goes on for so long that editors have dismantled sections of the final scene and credited them to later productions ${ }^{14}$. $\mathrm{He}$ lingers on the stark and vibrant details of his devolution, his maimed body becoming the template upon which tragic language lavishes its boldest effects. As he fully recognizes himself as an object of insult and expatiates on the details of his criminal acts, he also continues to engage in what we might call directorial gestures, but now with full focus on his own form. That is to say, his transformation into blind and wounded criminal, the perfect target of insult, runs parallel to his manipulation of tragic viewing. What emerges, I think, is an aesthetic event that is unique to Greek tragedy, and possible uniquely Sophoclean: the abusive hero's oversight of his defiled body's tragic impact ${ }^{15}$.

First the messenger declares that Oedipus is demanding to be revealed to "all the men of Thebes" (i.e., the chorus members and by implication the Athenian audience): "He shouts

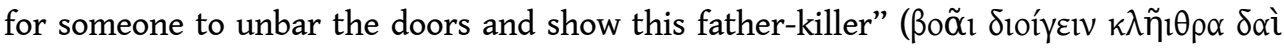

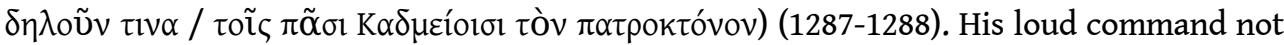
only dramatizes the hero's distress; it is also stage business: "Open the skênê doors ${ }^{16 ! " ~ A n d ~}$ the messenger obediently characterizes the aesthetic effect: "Soon you will see a

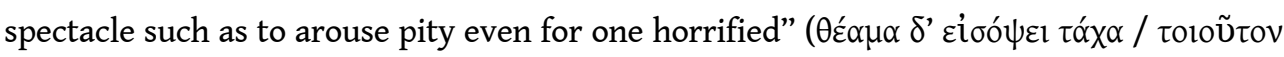

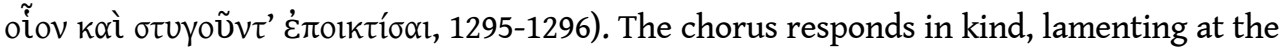

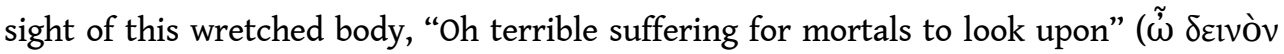

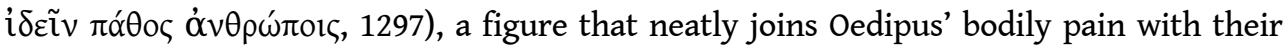
own at seeing him. They soon claim that they cannot look at him ( $\dot{\alpha} \lambda \lambda^{\prime}$ ov่ $\delta^{\prime} \dot{\varepsilon} \sigma 1 \delta \varepsilon \tilde{v}$ / $\delta u ́ v \alpha \mu \alpha i ́$ $\sigma \varepsilon)$, although, as they state in a pairing that must have influenced Aristotle,

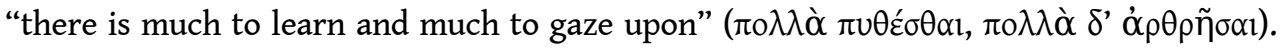
And they add a comment on the frisson that audience reaction to tragic effect entails:

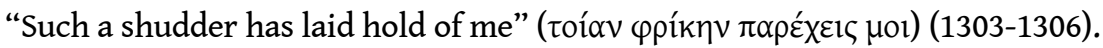

To the chorus' question as to how he could dare to put out his own eyes, Oedipus responds in a manner that again has double resonance as a hero's distress and a comment on tragic spectacle - now what amounts to a direct rejection of it: "Why is there any need

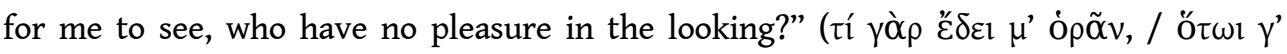

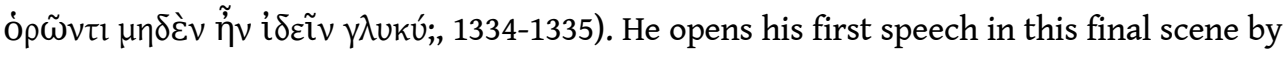


asking again what he could possibly look upon with pleasure, rejecting even the thought of his children as desirable objects of sight (1371-1377). He laments that he, "raised the

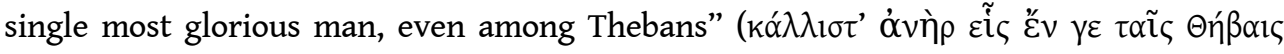

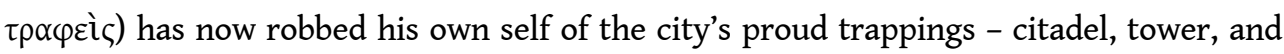
statues of the gods - by unknowingly cursing the criminal. And he declares,

$\dot{\alpha} \lambda \lambda^{\prime} \varepsilon \dot{\imath} \tau \tilde{\eta} \varsigma \dot{\alpha} \kappa o v o u ́ \sigma n \varsigma$ हैं $\tau^{\prime} \tilde{\eta} v$

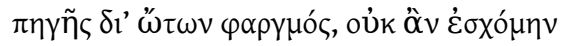

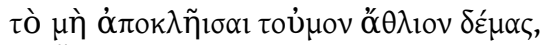

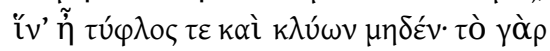

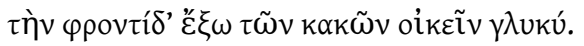

If there were a protection from hearing

for the fountain of my ears,

I would not hold back from locking up my

wretched carcass, so that it would be blind and

hear nothing. For to keep thoughts dwelling

outside of evils is sweet. (1386-1390)

In this recounting of his horrors Oedipus also achieves an exquisite calibration of antitragic aesthetics, moving from one sense to another and rejecting any pleasures that might be counted among tragedy's bitter joys. His "wretched body," which is this moment's ideal object, seems to him something to be locked away, its senses cut off from any but the mildest of thoughts ${ }^{17}$. It had, he now understands, always been a monstrous thing, for all its original beauty - "fairness," as he says, "with an under-festering of evils"

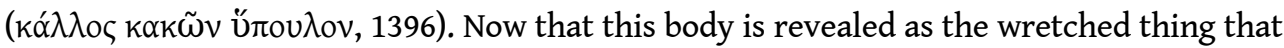
it is, he matches his desire for its release from painful sights and sounds with a demand that it be treated as should any properly recognized object of repudiation. He insists that he be tossed out or killed or covered over by the sea, so that he can never be looked upon

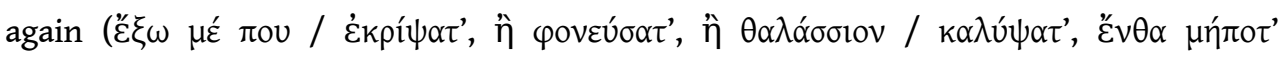

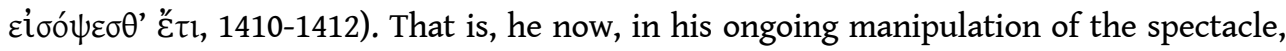
desires to remove himself from the stage as an object of tragic pleasure, since he regards himself instead as a target for abuse.

When Creon arrives on stage he agrees with this removal, though his solution is not exile (or drowning) but the oikos. Thus his stage directions focus on the skênê: he wants Oedipus covered up and brought inside, where not only no human but no god such as Helios, nor

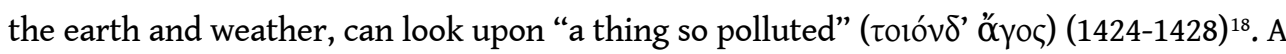
tussle ensues, effectively over alternate endings, which has encouraged editors' rejection of the various sections of the last hundred lines of the play. For our purposes, however, it is important that this moment also engages a face-off between abusive and tragic registers, as the tension mounts over alternate means of disposing of this reviled object, which in turn perversely contributes to the power of its attraction. Thus Oedipus' and Creon's insistence on the necessity of confiscating his athlios demas only heightens the intensity of the vision. Here in the play's final moments one might finally see tragedy's perfect target - the abject and exquisite (near) corpse.

\section{Oedipus Prized and Cursing}

In Oedipus Tyrannos the king's transformation from kallistos to athlios appears to render him more approachable both at this play's end and in Oedipus at Colonus. This startling difference is marked particularly by what theorists of theater semiotics call proxemics 
(i.e., nearness indicators) ${ }^{19}$. While Oedipus remains the bold king with his senses physically intact, his only gestures toward others are commanding or abusive and tinged with violence. When, in contrast, he is blind and debilitated, he seeks fond physical contact with his daughters (Oedipus Tyrannos 1480-1483) and connections with or concessions from others (1321-1323, 1469-1474, 1503-1510).

Lowell Edmunds has remarked on the ways in which Oedipus at Colonus foregrounds the body of the debilitated exile, placing it in careful proxemic counterpoint to other characters and ultimately ushering it offstage with some ritual pomp ${ }^{20}$. While there is little question that this late drama frames Oedipus from the outset as a debased and outcast presence, the tensions it generates around his status appear to foster rather than impede communication. Although, for instance, the old men of Colonus who make up the chorus exhibit an expected horror upon seeing and hearing Oedipus (e.g., he is

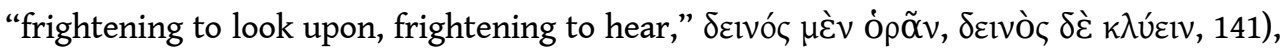
they are also quick to reach agreement with him on how he ought to be received. Oedipus may in his weakened and foul state seem similar to Philoctetes; and yet his aged, fatherly rank and carefully handled body (especially by Antigone, who remains proximate through much of the action) achieve for him a more valuable and august function within the civic and the aesthetic schemes.

From the outset Oedipus and others accord him and his body a special consideration and highlight its strange status. For instance, in a moment familiar for Sophoclean heroes,

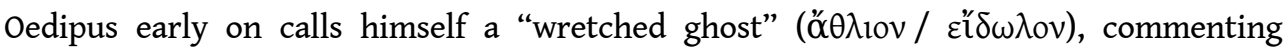

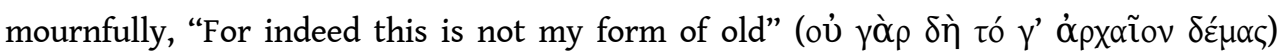
(109-110). Central to this negotiation of mysterious embodiment are the interactions of Oedipus and Theseus, who treat each other with grace and respect. In a gesture that effectively cauterizes his status as wounded agos, Oedipus offers the king his "wretched

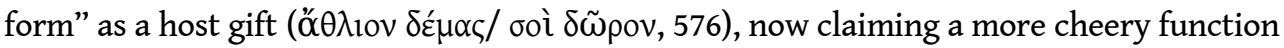

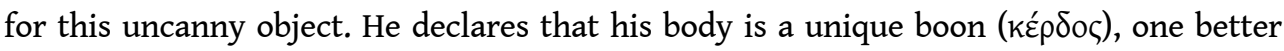
than that provided by the beautiful shape ( heroes (576-578). And although Theseus cannot quite parse this figure at the moment of its offering, he soon shows his understanding of how important it is to defend ${ }^{21}$.

This exchange in particular opens up the possibility that the abject body of the outcast hero may be received - by Theseus, by Athens, by Athenian audiences - as an object

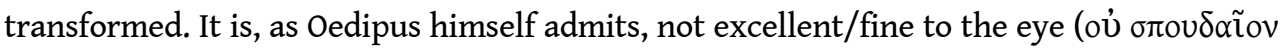

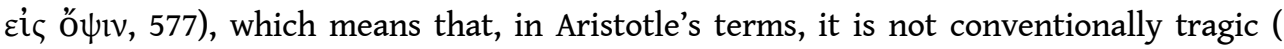
Poetics 1449b24-25; cf. 1448a1-2, b34-35). But its peculiar state renders it very valuable, a benefit to those who would hold and protect it, as the ensuing struggles between Creon and the chorus, then Creon and Theseus, and finally Polyneices and Oedipus dramatize most fully. Civic and citizen reputations are dependent on this wretched body's safekeeping; and the violent types of touch with which the contenders threaten it and each other only heighten awareness of its special status. Not only is it no simple object of insult, it is also better than a conventionally beautiful body, and better than a merely heartbreaking one. It is simultaneously moving and unnerving, an anomalous thing within the aesthetic scheme. This is precisely the confluence that Kristeva characterizes as central to the abject, especially in relation to Oedipus when he is at Colonus: sublime or perverse? revolting or sacred? 

abject figure that Oedipus has become, which is framed as a distinctly Athenian context, stand the Theban characters who enter Colonus from outside of Attica: Creon and Polyneices. Creon comes across as the double-talking villain that Oedipus thinks he is (and that he is not) in Oedipus Tyrannos, while Polyneices' aggressive pleading with Oedipus only conforms to his earlier ill treatment of his father. In fact, the play distinguishes quite clearly between those who speak wisely and to good effect and appear capable of "seeing" Oedipus correctly (the chorus, Theseus, and Antigone), and those who do not (Creon and Polyneices).

Familiar terms of abuse and approbation cluster on either side of this divide. Most tellingly, Oedipus responds to Creon's attempts to force him back to Thebes by characterizing him as bold and crafty: "Oh you who are all-daring and who wrest an

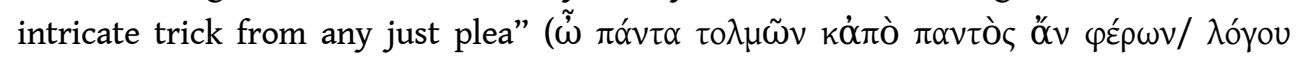

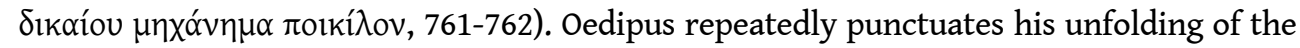
wrongs done him by means of such verbal slights. Creon is a man who "says harsh things

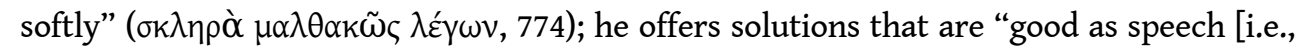

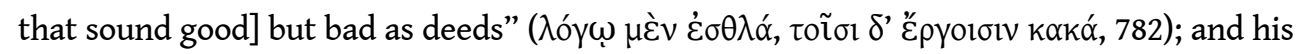

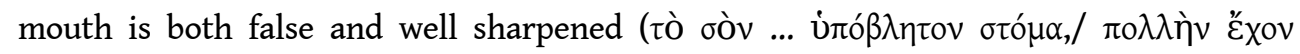

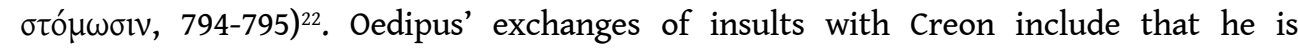

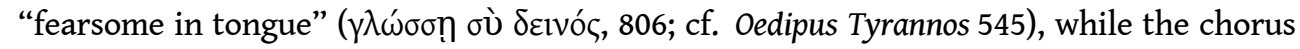
leader confirms this, responding to his threats by declaring, "You do speak fearsomely"

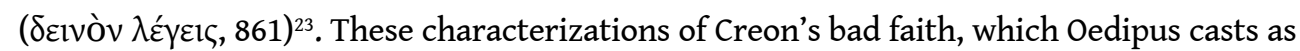
rhetorical - the dissimulating, devious speech of one engaged in subterfuge - contrast sharply with the ways in which Oedipus is deinos: that is, as a body to witness and to target or defend.

When Polyneices finally appears onstage like Creon before him he remarks on the appearance of Oedipus in his exiled state, but in more detailed physical terms. He enters weeping, and then immediately asks whether he should not cry more for his father's dilapidation, the features of which he then enumerates:

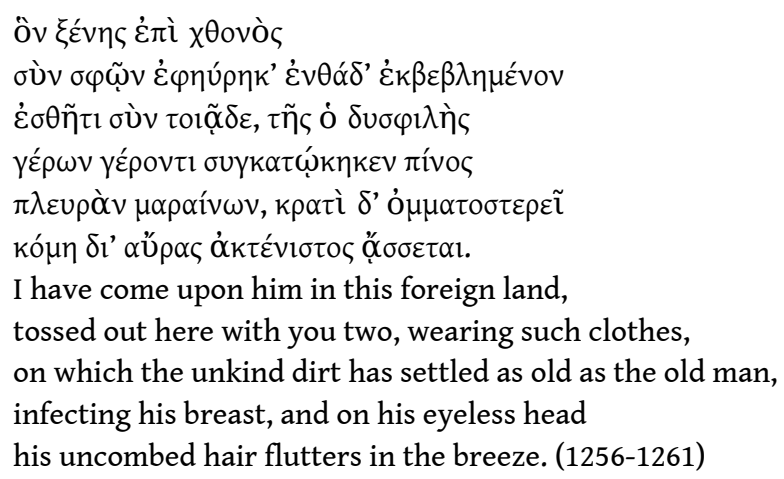

Polyneices' portrait of his father, late as it comes in the action, adds another layer of aesthetic response and information to the accumulated effects of this special body. The details of appearance he offers perform a function quite opposite to the distancing and elevated viewing of tragic bodies as abject, terrifying, and extreme. Polyneices encourages a different kind of gaze, a more intimate, homely, and debasing one that emphasizes the old clothes, the fluttering hair.

Oedipus will have none of this. As Polyneices seeks to handle him verbally and physically, he rejects any notion that he is to be targeted as or reacted to as any regular old body.

Cahiers « Mondes anciens », 5 | 2014 
Oedipus stands in silence and then turns his back on his son; and when he finally does speak it is in fury and insult. Violently rebuffing Polyneices' attempts at tearful reconciliation, Oedipus states first that he has only given his son an audience to please his

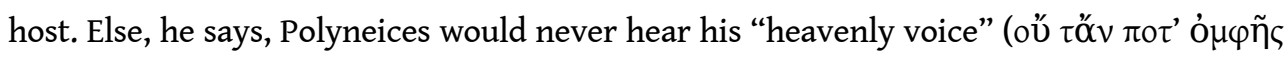

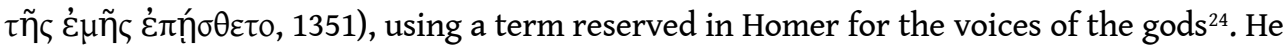
blames Polyneices for his exile and the very guise he laments (i.e., the foul clothes, 1354-1357), so that, meta-theatrically and aesthetically speaking, he attributes the more humble aspects of his status and visible persona to him.

Oedipus' furious tone soon escalates to a kind of oracular invective, in keeping with his warning about his divine voice. He declares the brothers no sons of his, claims that an evil daimôn has his eye on Polyneices, and foretells that he and his brother will fall, tainted

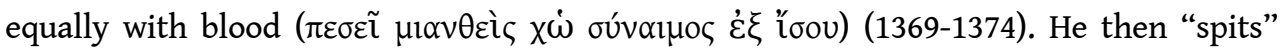

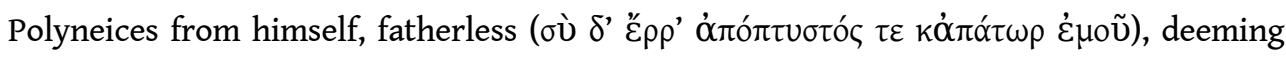

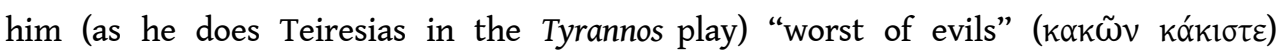
(1383-1384, cf. 1354). In fact he curses his son repeatedly (1371, 1384, 1389-1392), finally

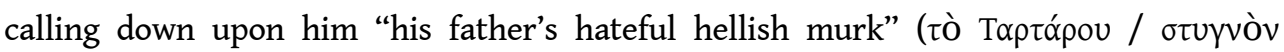

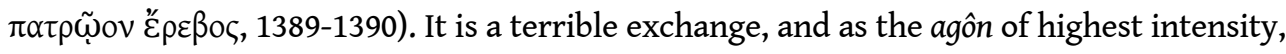
it furnishes an appropriately shocking entrée to Oedipus' portentous exit from the stage and from life.

Oedipus thus breaks with the palliative style he employs for exchanges with Athenians to insult another Theban - a turn that could be anticipated but is nevertheless disturbing, coming here so late in the drama and so far down the path of his fate ${ }^{25}$. And yet this brutal oracular tone does, from my perspective, suit the mysterious object Oedipus' body has become, since at this late stage he is undergoing a final transformation from abject and piteous to, quite literally, sublime (i.e., near heavenly) ${ }^{26}$. In his final moments onstage, we see this elevated aesthetic played out in emphatic terms. Now, as a lofty object Oedipus cannot be handled, as he warns his daughters: "Come forward, but do not

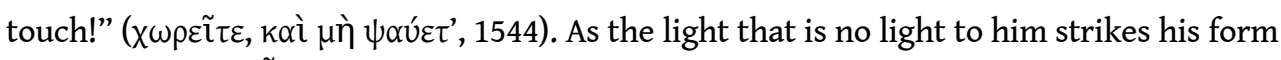

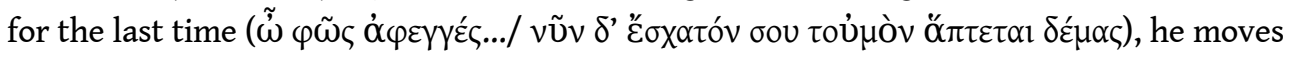
slowly (ع $\rho \pi \omega)$ off the stage, exclaiming in priestly fashion to his host and company,

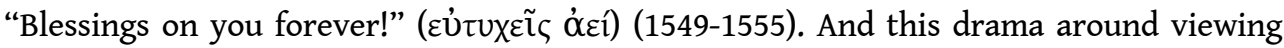
the tragic form continues in the messenger's speech: when Oedipus vanishes Theseus shades his eyes, as if in fear of some terrifying sight that he could not endure (ö $v \alpha \kappa \tau \alpha \delta$,

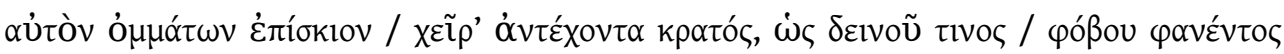

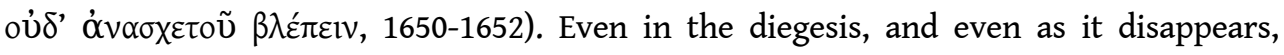
Oedipus' body sustains its unique character as a tainted and yet stunning object.

We might ask, by way of conclusion, whether any novel understanding of tragic representation and its peculiar pleasures emerges from this emphasis on the ways in which violent, targeting language and stage directions shape perceptions of heroic stature. Since Attic tragedy did not make much use of costumes and props (as far as can be determined from the slight and late evidence ${ }^{27}$, the insults, shocked reactions, and directorial gestures imbedded in Sophocles' Oedipus plays effectively told the original audience what to see, and how to perceive what they saw, even when they were looking directly at the actor's body onstage. Tragic enactment built this unique aesthetic entity largely from verbal cues - abusive, commanding, or otherwise - that achieve a heightened semiotic impact by their combination with visual effects, such as the body's disposition and placement on the dramatic stage ${ }^{28}$. Although it may be difficult for 
modern readers and audiences to imagine such visual austerity, it must, I think, have only contributed to the unnerving, hybrid impact of tragic expression. Further, focusing on insults aimed at heroic stature opens a distinctive angle on this impact, foregrounding frictions between abject and debased bodies on the one hand and powerful, elevating, visualizing language on the other. As the debilitated Oedipus declares at Colonus, to the stranger who first lays eyes on him and asks what help a blind old man can be, "There

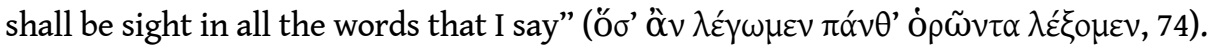

\section{BIBLIOGRAPHY}

Elam K. (1980), The semiotics of theatre and drama, London.

Edmunds L. (1996), Theatrical space and historical place in Sophocles' Oedipus at Colonus, Lanham. Issacharoff M. (1989), Discourse as performance, Stanford.

Knox B. (1957), Sophocles, New York.

Kristeva J. (1982), Powers of horror, New York.

Kuhns R. (1982), “The beautiful and the sublime”, New Literary History 13-2, p. 287-307.

Murnaghan S. (1988), "Body and voice in Greek tragedy", Yale Journal of Criticism 1, p. 23-43.

Nooter S. (2012), When heroes sing: Sophocles and the shifting soundscape of tragedy, Cambridge.

North H. (1991), “Combing and curling: Orator summus Plato”, Ios 16, p. 201-219.

Ober J. (1989), Mass and elite in democratic Athens: Rhetoric, ideology, and the power of the people. Princeton.

Olson S. D. (1989), “On the text of Sophocles 'Oedipus Tyrannos' 1524-1530”, Phoenix 43-3, p. 189-195.

Panoussis I. (2002), Crainte et violence dans le théâtre de Sophocle, Villeneuve d'Ascq.

Pfeiffer-Petersen S. (1996), Konfliktstichomythein bei Sophokles: Funktion und Gestaltung, Serta Graeca: Beiträge zur Erforschung griechischer Texte, bd. 5, Wiesbaden.

Pickard-Cambridge A. W. (1968), The dramatic festivals of Athens, Oxford, 1968.

Pope M. (1992), “Addressing Oedipus”, G\&R, 38-2, p. 158-170.

Porter J. (2010), The origins of aesthetic thought in ancient Greece: Matter, sensation, and experience, Cambridge.

Ramazani R. J. (1989), “Yeats: Tragic joy and the sublime”, PMLA 104-2, p. 163-177.

Reinhardt K. (1988), Sophocles, New York.

Ronnet G. (1969), Sophocle: Poète tragique, Paris.

Seale D. (1982), Vision and stagecraft in Sophocles, Chicago. 
Segal C. P. (1993), "Inner vision and theatrical spectacle", in Oedipus Tyrannos: Tragic heroism and the limits of knowledge, Oxford, p. 123-130.

Ubersfeld A. (1977), Lire le théâtre, Paris.

Worman N. (1999), “The Ties that Bind: Transformations of Costume and Connection in Euripides' Heracles", Ramus 28-2, p. 89-107.

Worman N. (2001), “The herkos Achaiôn transformed: Character type and spatial meaning in the Ajax", CP 96, p. 230-254.

Worman N. (2008), Abusive mouths in classical Athens, Cambridge, 2008.

Zeitlin F. I. (1991), “Euripides' Hekabe and the somatics of Dionysiac drama”, Ramus 20, p. 53-94.

\section{NOTES}

1. Reinhardt 1988, p. 99 : "Etwas, was der attischen Tragödie als ganzer Erscheinung eigen ist, das Schwelgen im Furchtbaren, das Gemeng von Grauen und Wollust...."

2. Kristeva 1982, p. 83-89.

3. See Worman 2008.

4. Homeric epic shows awareness of such conflicts: Odysseus famously rebukes both Euryalus and Antinoos for not having words and/or disposition to match their high statuses and fine statures ( Odyssey, 8.174-79, 17.454); conversely, Odysseus as castaway and then beggar must work hard to offset his sullied form with graceful words (as with Nausicaa and Penelope in Odyssey 6 and 19).

5. On the complexities of semiotic reference in drama, see Ubersfeld 1977 ; Serpieri 1978 ; Elam 1980 ; Issacharoff 1989.

6. Reinhardt 1988, p. 99 : “...ist heir das der Opfer und der Schwelgende, sich Windende und auf sich Zeigende, aus seiner Qual Aufblühende, besessen Redence und Singende ein und derselbe." Reinhardt does also mention Heracles, but insists that Oedipus' dramatic self-indicating is distinct.

7. See Panoussis 2002, p. 39-51, on Oedipus' violent tendencies. Oedipus is also surrounded by those who would or should do his will, as his repeated designation as tyrant (tyrannos, tyrannis) reinforces. Both Oedipus and most of his interlocutors refer to him as such. Pope (1992, p. 157) has argued that, given Athens' and other city-states' relatively recent history with tyrants, the ancient audience would have felt the difference between kingship and tyranny. On this account, kingship would have represented the more legitimate sovereignty, familiar from Homer; tyranny is the result of a coup.

8. See Knox 1957, ch. 4 ; also Ronnet 1969, p. 58-59 and 67, who thinks that this staging highlights the sharp contrast between "Oedipe dans toute sa grandeur" (58) and his later devolution ("l'affreuse chute d'Oedipe," 67). Cf. Euripides' Heracles, in which the clustering of Heracles' family at the kallinikos statue that the hero dedicated to Zeus at the opening of the play contrasts jarringly with his collapsed state at the end, when he sits slumped and tied to a broken pillar of his palace (see Worman 1999).

9. Neither Teiresias nor Creon gives Oedipus any obvious reason for his suspicions, beyond being slow to tell him what he wants to hear. Bernard Knox once remarked on the strangeness of readers' insistence that Oedipus Tyrannos is a play about fate (op. cit., p. 3-14); and at no juncture is this notion more clearly challenged than when the hero's quick anger and outsized insults prevent him from hearing the seer, which drives forward the plot he has so cleverly devised. Of course, in the Oedipus at Colonus Oedipus offers just this reading of his fate: he is not responsible, a plaything of the gods, etc. 
10. I owe my rethinking of the difference in the speakers' modes in this scene to the comment of Manuela Giordano, for which I am very grateful.

11. On this reversal of terms see Pfeiffer-Petersen 1996, p. 74-75.

12. Note that $\pi \rho \circ \pi \eta \lambda \alpha{ }^{\prime} \iota_{1 \zeta \varepsilon}$ is a term of insult in Plato (e.g., Republic, 329b, 536c, 562d) and oratory (e.g., Demosthenes, 9.60, 18.12, 18.256 ; Aeschines, 3.258).

13. This is the type of moment in tragic revelation that Aristotle captures as "this man is that one" (oŨ்o $\tilde{\varepsilon} \kappa \varepsilon \tilde{v} v o \varsigma$, Poetics, 1448b17); here the audience would make the connection, even if the hero and chorus do not.

14. See Olson 1989, for bibliography and overview; also Dawe's commentary (rev. ed. 2006, p. 192-193).

15. Cf. esp. Heracles at the end of Trachiniae. On Euripides' treatment of some aspects of this dynamic, see Zeitlin 1991.

16. Reinhardt emphasizes Oedipus' oversight of this revelation (op. cit. p. 140). See also Seale 1982 and Segal 1993, p. 123-130. Panoussis 2002, p. 151-152, oddly thinks that Oedipus is relatively passive in this scene.

17. On this emphasis on sense perception, especially aural, see Bollack, ad loc.

18. Again, Kristeva 1982, p. 83-86 emphasizes the importance of Oedipus as agos.

19. See Elam 1980, p. 56-69.

20. Edmunds 1996 ; see also Murnaghan 1988, p. 23-43.

21. As this "gift" indicates, their first exchange in fact bears features common to xenia interactions between aristocrats.

22. Note that Sophocles sustains this negative emphasis on Creon's stoma, deeming his mouth

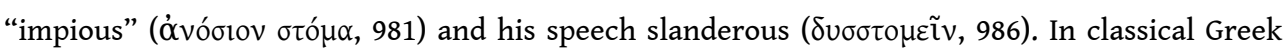
literature, when speakers focus on mouths it is usually to insulting effect (see Worman 2008). For a thoughtful discussion of mouth imagery in the Oedipus at Colonus, see Nooter 2012, p. 167-175.

23. The most common charge for a speaker such as this, who in tragedy tends to be personified by Odysseus, is that he is deinos legein, "fearsome at speaking." Deinos encompasses much more than simply powerful, however ; it indicates an ability that is strange and terrible in its force and therefore never very positive in its effects. Speakers in democratic assembly level such charges at their opponents, in order to single them out as too polished, clever, and thus untrustworthy. E.g., Aeschines, 3.174 ; Lysias, 12.86 ; Demosthenes, 20.146, Exordia, 32.1 ; Plato, Apology, 17b1-4. Cf. Euripides, Trojan Women, v. 968 ; fr. 442 ; Sophocles, Philoctetes, v. 440. See North 1991, p. 201-219 ; Ober 1989, p. 170-171.

24. See Nooter 2012, p. 107-171.

25. Nooter (2012, chap. 5) associates this brutal tone with Oedipus' increasing verbal authority. In her account, it is of a piece with his steady turn to prophetic, commanding, and ominous speech, speech that is closely connected to the gods and then finally uttered by one about to enter the divine realm himself.

26. See, e.g., Kuhns 1982 ; Ramazani 1989 ; also for ancient aesthetics see Porter 2010.

27. E.g., Athenaeus, 1.21d; Philostrates, De Vita Apollonii, 6.11. Pickard-Cambridge (1968, p. 177-180) points out that Julius Pollux, the second-century A.D. source, refers only rarely to actual plays, and may have relied on Hellenistic sources for his general remarks. PickardCambridge (p. 180-209) also notes the limitations of the visual evidence, although he frequently makes use of it in his discussion. Csapo and Slater (1995, p. 256-257), point out the prejudices of even contemporaneous sources, and thus argue that only artifacts provide dependable evidence.

28. See Worman 1999, 2001. 


\section{ABSTRACTS}

Tragedy contributes something unique to intersections of the body and language, and this contribution has to do with the aesthetics of abuse. These aesthetic effects are dependent on the layered quality of dramatic semiosis, which builds up from the language of the text to the possibilities of its performance. Within this dramatic frame, the most dilapidated and targeted of forms may replace the most heroic as objects of reverence precisely because of the paradoxical qualities of tragedy's aesthetics. Conversely, the glorified figure may appear debased, by virtue of his mistaken place in the order of things. My primary example is Oedipus, who in Oedipus Tyrannos issues curses at an as yet unidentified criminal, a kakourgos of the basest sort, and threats to the blind and decrepit seer Teiresias. His insults revolve ultimately upon his own status and stature, since he emerges at the end of the drama as the target of his own abuse, both criminal and blind. Only then might he, in this new debilitated state, become an object of tragic pleasure. The king's transformation from kallistos to athlios also appears to render him more approachable both at this play's end and in Oedipus at Colonus. This startling difference is marked particularly by what theorists of theater semiotics call proxemics (i.e., nearness indicators). While Oedipus remains the bold king with his senses physically intact, his only gestures toward others are commanding or abusive and tinged with violence. When, in contrast, he is blind and debilitated, he seeks fond physical contact with his daughters and connections with or concessions from others. A fuller understanding of tragic representation and its peculiar pleasures emerges from this emphasis on the ways in which violent, targeting language and stage directions shape perceptions of heroic stature.

La tragédie contribue de façon unique aux croisements entre le corps et le langage et, dans cette perspective, cette contribution entend réfléchir sur l'esthétique de l'abus. Ces effets esthétiques dépendent de la texture feuilletée de semiosis dramatique, qui se fonde autant sur la langue du texte que sur les possibilités ouvertes par la mise en scène. Dans ce cadre dramatique, les formes les plus délabrées peuvent remplacer les plus héroïques comme objets de vénération précisément à cause des qualités paradoxales de l'esthétique tragique. À l'inverse, une figure glorifiée peut apparaître rabaissée, en vertu de son placement erroné dans l'ordre des choses. J'analyse à cette aune le cas d'ÆEdipe qui, dans ÆEdipe Tyran, profère des malédictions à l'encontre d'un criminel encore non identifié, un kakourgos de la pire espèce, tout en menaçant Tirésias, le voyant aveugle et décrépit. Ses insultes atteignent en fin de compte son propre statut et stature, puisqu'il apparaît à la fin du drame comme la cible de ses propos abusifs, à la fois criminel et aveugle. C'est alors seulement qu'il peut devenir, dans ce nouvel état de déréliction, un objet de plaisir tragique. Cette métamorphose du roi - qui, de kallistos devient athlios - semble aussi le rendre plus accessible tant à la fin de cette pièce que dans $E$ dipe à Colone. Cette différence ahurissante est marquée particulièrement par ce que les théoriciens de la sémiotique théâtrale appellent "proxémie » (c'est-à-dire des indicateurs de proximité). Tant qu'Edipe reste un roi hardi avec tous ses sens intacts, ses seuls gestes vis-à-vis des autres sont autoritaires, voire abusifs et teintés de la violence. Quand, au contraire, il est aveugle et affaibli, il recherche un contact physique affectueux avec ses filles et fait des concessions avec ceux qu'il rencontre. En soulignant la façon dont un langage violent et des indications scéniques ciblées contribuent à construire la 
perception de la stature héroïque, on espère atteindre une compréhension plus complète de la représentation tragique et de ses plaisirs particuliers.

INDEX

Mots-clés: tragédie, insulte, đdipe, esthétique, incarnation, proxémie, stature héroïque, performance

Keywords: tragedy, insult, Oedipus, aesthetics, embodiment, heroic stature, proxemics

\section{AUTHOR}

NANCY WORMAN

Barnard College, Columbia University 